\title{
Justification of elements of rice cultivation technology
}

\author{
Nadezhda Malysheva ${ }^{1}$, Anna Khadzhidi ${ }^{1}$, Evgeny Kuznetsov ${ }^{1}$, Noureldin Sharaby ${ }^{2,3}$ and \\ Alexander Koltsov ${ }^{2, *}$ \\ ${ }^{1}$ Kuban State Agrarian University named after I.T. Trubilina, 13, Kalinina str, 350044, Krasnodar, \\ Russia \\ ${ }^{2}$ Don State Technical University, 1, Gagarin sq., 344003, Rostov-on-Don, Russia \\ ${ }^{3}$ Kafrelsheikh University, El-Geish Street, 33516, Kafr el-sheikh, Egypt
}

\begin{abstract}
The purpose of the research is to identify the impact of sprinkler irrigation in rice crop rotation on rice productivity and soil fertility of irrigated lands of the Krasnodar region. To achieve this goal, the tasks of studying the density of weed seedlings after sprinkler irrigation, the content of water-soluble salts and humus in the soil of rice fields, and the reaction of an intensive variety of rice cultivated after irrigation and drainage techniques in rice fields were completed. Material and methods. Field studies were carried out on the Kuban irrigation system of the Krasnodar territory, which is the most typical in terms of soil conditions for the western climatic zone of the region, with various variants for sprinkler irrigation after major planning of basins. An intensive of Rapan rice variety was used. The methods of the Federal Research Center for Rice, the Kuban State Agrarian University, and Russian standards were applied. Conclusions, the obtained results of the conducted studies prove the effectiveness of sprinkler irrigation in rice crop rotation, increase soil fertility, rice productivity, and contribute to the production of environmentally friendly products without herbicides treatment.
\end{abstract}

\section{Introduction}

The reclamation complex of the Krasnodar Territory is represented by twelve rice irrigation systems with a total area of 234.4 thousand ha, which are used in crop production and are an integral part of the agro-industrial complex of the Krasnodar Territory of the Russian Federation. The Kuban irrigation system, which is located in the Krasnoarmeysky district of the Krasnodar Territory on a total area of 33.2 thousand ha, is the most typical soil condition for the western climatic zone of the region. humus-gley, peat-gley, and meadow-bog soils are widespread in the Kuban irrigation system, which have undergone significant changes during the rice growing season under the influence of constant flooding and need to improve their fertility $[1,2,3]$.

Rice is grown annually in the region on an area of about 130.0 thousand ha, and the gross grain harvest is about 900.0 thousand tons in offset weight. Rice productivity over the

\footnotetext{
*Corresponding author: coltsov.sanya@yandex.ru
} 
past 10 years has increased from $6.05 \mathrm{t} / \mathrm{ha}$ in 2009 to $6.61 \mathrm{t} / \mathrm{ha}$ in 2018 with an average value of $6.18 \mathrm{t} / \mathrm{ha}$ which is higher than world indices by $1.77 \mathrm{t} / \mathrm{ha}$ and the productivity in the Russian Federation by $0.71 \mathrm{t} / \mathrm{ha}$ (Figure 1 ).

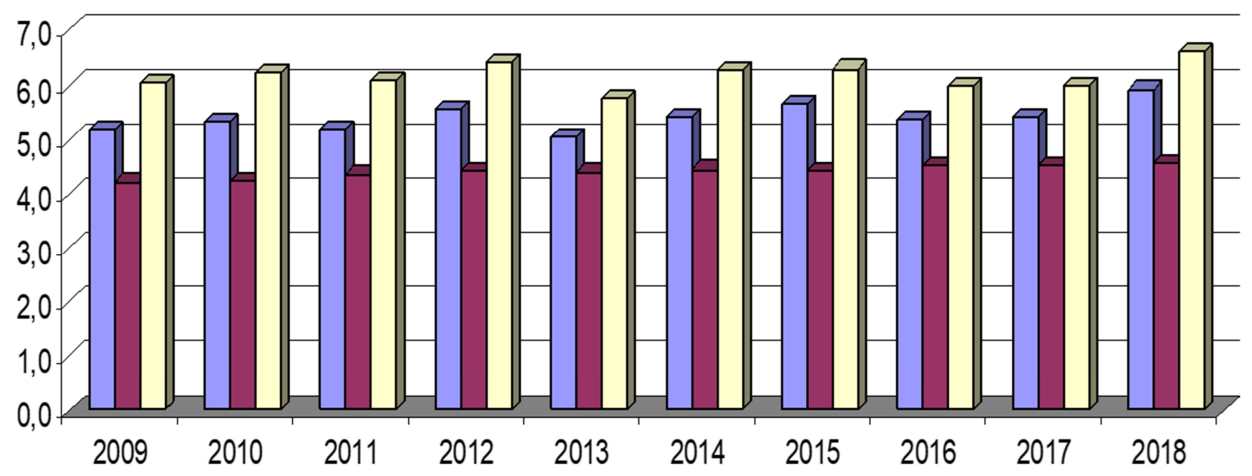

Rice productivity in the Russia, $t$ /ha

Rice productivity in the world, $t /$ ha

Rice productivity in the Krasnodar Territory, $t /$ ha

Fig. 1. Rice productivity in the world, Russia and the Krasnodar Territory, 2009-2018.

One of the important factors in the further development of rice production in the Kuban system is to increase industrial efficiency, increase rice yield and grain production. The solution to these issues largely depends on the technology of rice cultivation and the reclamation state of rice systems [4].

In Russia, as in the Krasnodar Territory, the technology of direct rice sowing is used, there is no monocrop and crop rotation are used, in which rice is sown on one field for no more than three years. Moreover, rice is not sown on a rice basin; but a set of agro-technical and land reclamation measures is carried out to reconstruct hydraulic structures, repair the layout of basins and restore soil fertility.

The repair layout of rice nurseries (basins) are the basis for the creation of effective agricultural technologies; it contributes to saving irrigation water, observing the irrigation regime during the phases of rice vegetation, shortening the growing season and conducting timely harvesting, increasing plant productivity and grain production volumes $[5,6]$. However, when performing these works, a large amount of soil moves along the basin, on the soil surface, there are a large number of weed seeds and red rice, which for a long time were in the lower layers of the soil and retained their viability [7]. When rice is sown in spring, seedlings of varietal plants outstrip rice plants in development, reduce seed germination, and compete with rice for the main factors of life - everything, water, mineral nutrition. Therefore, it is necessary to treat crops with herbicides, which is not economically profitable for farmers. in addition, the use of pesticides affects the quality of grain, pollutes the environment.

Therefore, sprinkler irrigation after the repair layout of basins allows to improve the soil structure of rice fields, to obtain seedlings of weeds (Echinóchloa, Bolboschoenus) and wild red rice (Oryza rubrum), to destroy them before the rice is planted, to reduce the cost of herbicides or not to use them, to increase quality of the marketable grain, improve the state of the environment [8]. These are urgent tasks facing the agro-industrial complex and their solution is due to systematic work in the fields of rice crop rotation.

There is an urgent need to recommend that farmers should include mandatory sprinkler irrigation in the technological process of rice cultivation in the crop rotation system, 
provided that there are sufficient water resources during the rice growing season, which will ultimately have a positive effect on the economy of the agricultural business.

Therefore, the main purpose of these studies is to identify the impact of sprinkler irrigation in rice crop rotation on rice productivity and soil fertility of irrigated lands of the Krasnodar Territory. To achieve this goal, there are some tasks were performed such as; studying the density of weed seedlings after sprinkler irrigation, the content of watersoluble salts and humus in the soil of rice field, the yield of the intensive Rapan rice variety, after agro-reclamation techniques on rice basins.

\section{Materials and methods}

Field studies were conducted on the Kuban irrigation system of the Krasnodar Territory. Sprinkler irrigation after repair planning of rice basins was carried out on the OL-2 system, map 18, basin $1(\mathrm{~S}=5.2 \mathrm{ha})$, basin $2(\mathrm{~S}=5.8 \mathrm{ha})$, basin $3(\mathrm{~S}=6.0 \mathrm{ha})$ according to the following experimental variants: I - repair layout of basins without sprinkler irrigation (control), obtaining weed germination due to precipitation; II - repair layout of basins with one sprinkler irrigation; III - repair layout of basins with two consecutive sprinkler irrigation.

In the experiment, counts and observations were carried out according to the methods of the Federal Scientific Center for Rice (Krasnodar), Kuban State Agrarian University: accounting for the volume of water supplied for sprinkler irrigation; counting weeds; determination of water-soluble salts and humus in the soil, irrigation rate; accounting for field germination of rice and productivity. The counting of weeds was carried out with a PPV of $80 \%$. For sowing, an intensive variety of Rapan rice was used with potential yield around $11.0 \mathrm{t} / \mathrm{ha}$ and a growing period of 128 days. The variety is depending on nitrogen nutrition, but also depends on a very adaptive and suitable various growing technologies. In this work, the Russian standards for the operation of irrigation systems was used, the implementation of repair planning, metering water for irrigation of rice and sprinkler irrigation, for the care of rice plants and determining the yield.

\section{Results and discussion}

In the control variant, after carrying out the repair layout of the basins, seedlings of weeds were obtained due to precipitation, the amount of which was $74 \mathrm{~mm}$ or $38.5 \mathrm{~m} 3$ during the growing season. In the experimental variants of the experiment, when carrying out one sprinkler irrigation, the volume of water supply was $1754 \mathrm{~m} 3(+1715.5 \mathrm{~m} 3$ to control), while for two irrigation was $-3628 \mathrm{~m} 3$ (+3589.5 m3 to control).

A further calculation of the germinated weeds showed that, when germination was obtained due to precipitation, their number average was $65 \mathrm{pcs} / \mathrm{m} 2$, including Echinóchloa $28.6 \mathrm{pcs} / \mathrm{m} 2$, Bolboschoenus $13.7 \mathrm{pcs} / \mathrm{m} 2$ and $22.7 \mathrm{pcs} / \mathrm{m} 2$ for Oryza rubrum (Table 1).

Table 1. The number of sprouted weeds and wild red rice after sprinkler irrigation in the crop rotation.

\begin{tabular}{|c|c|c|c|c|c|c|c|c|c|c|c|c|c|}
\hline \multirow{3}{*}{$\begin{array}{c}\text { Experiment } \\
\text { Variants / } \\
\text { accounting } \\
\text { sites } \\
\end{array}$} & \multicolumn{13}{|c|}{ The number of sprouted weeds. pcs $/ \mathrm{m} 2$} \\
\hline & \multicolumn{4}{|c|}{ Echinóchloa } & \multicolumn{4}{|c|}{ Bolboschoenus } & \multicolumn{4}{|c|}{ Oryza rubrum } & \multirow[b]{2}{*}{ Total } \\
\hline & $\mathrm{I}$ & II & III & Avg. & I & II & III & Avg. & I & II & III & avg & \\
\hline $\mathbf{I}$ & 34 & 28 & 24 & 28.6 & 8 & 15 & 18 & 13.7 & 24 & 26 & 18 & 22.7 & 65 \\
\hline II & 102 & 112 & 98 & 104.0 & 28 & 34 & 26 & 29.3 & 59 & 48 & 38 & 48.3 & 181.6 \\
\hline III & 134 & 151 & 139 & 141.3 & 40 & 42 & 34 & 38.7 & 91 & 86 & 67 & 81.3 & 261.3 \\
\hline
\end{tabular}


Thus, in the test variants, the number of sprouted weeds after one sprinkler irrigation exceeded the control variant by 2.8 times, when carrying out two sprinkler irrigation, by 4.0 times and amounted to an average of $181.6 \mathrm{pcs}$ in the second variant of the experiment weeds per $1 \mathrm{~m} 2$, while in the third variant was around- 261.3 pcs weeds per $1 \mathrm{~m} 2$.

Consequently, when sprinkler irrigation is carried out in a crop rotation field after a repair plan, favorable conditions are created for the germination of weeds and wild red rice, and their timely mechanical removal with the help of disc tools can reduce the cost of herbicides next year and reduce their environmental impact land reclamation systems and the surrounding territories, where about 500 thousand people live.

After calculating weed vegetation according to the experimental variants and stabilization of the groundwater level in the experimental fields, water-soluble salts and humus in the soil were determined before treatment with disk implements (Table 2).

Table 2. The content of water-soluble salts and humus in the soil of rice fields according the experiment variants.

\begin{tabular}{|c|c|c|c|c|c|c|}
\hline \multirow{2}{*}{$\begin{array}{c}\text { Experiment } \\
\text { variants }\end{array}$} & $\begin{array}{c}\text { Depth of } \\
\text { selection. } \\
\mathbf{c m}\end{array}$ & $\begin{array}{c}\mathbf{N}-\mathbf{N O 3} \\
\mathbf{m g} / \mathbf{k g}\end{array}$ & $\begin{array}{c}\mathbf{N}-\mathbf{N H 4} \\
\mathbf{m g} / \mathbf{k g}\end{array}$ & $\begin{array}{c}\text { P2O 5. } \\
\mathbf{m g} / \mathbf{k g}\end{array}$ & $\begin{array}{c}\text { K2 O. } \\
\mathbf{m g} / \mathbf{k g}\end{array}$ & \multirow{2}{*}{ Humus\% } \\
\hline \multirow{2}{*}{ I } & $0-5$ & 2.09 & 0.42 & 10.5 & 5.8 & \multirow{2}{*}{2.21} \\
\cline { 2 - 6 } & $5-10$ & 2.04 & 0.42 & 10.5 & 5.6 & \\
\hline \multirow{2}{*}{ II } & $0-5$ & 1.95 & 0.54 & 11.5 & 7.0 & \multirow{2}{*}{2.38} \\
\cline { 2 - 6 } & $5-10$ & 1.84 & 0.51 & 11.0 & 6.9 & \multirow{2}{*}{2.60} \\
\hline \multirow{2}{*}{ III } & $0-5$ & 1.44 & 1.10 & 13.0 & 7.0 & \\
\cline { 2 - 6 } & $5-10$ & 1.38 & 1.04 & 12.2 & 7.0 & \\
\hline
\end{tabular}

The analysis results show that the smallest amount of humus was contained in the control variant of the experiment and was about $2.21 \%$. The maximum amount - in the third variant with two sprinkler irrigation $-2.6 \%$. Nitrate nitrogen in the maximum amount over the soil extraction horizons was contained in the control variant $-2.09 \mathrm{mg} / \mathrm{kg}$ and 2.04 $\mathrm{mg} / \mathrm{kg}$. The minimum amount in the third experiment was $1.44 \mathrm{mg} / \mathrm{kg}$ and $1.38 \mathrm{mg} / \mathrm{kg}$ at a depth of $0-5 \mathrm{~cm}$ and $5-10 \mathrm{~cm}$, respectively.

The decrease of the nitrate-nitrogen content in the soil according to the experimental variants is explained by its leaching during sprinkler irrigation and by being more active of denitrifying bacteria in moistened soil, which contribute to its conversion to molecular nitrogen $[8,9]$.

The maximum content of exchange potassium of $7.0 \mathrm{mg} / \mathrm{kg}$ by sampling horizons in the third experiment with two sprinkler irrigation in comparison with the control indicates that when water is supplied to the field after capital planning of the soil, a washing model is created and potassium salts are not are replaced by sodium salts, thereby creating a risk of salting $[4,10]$.

A similar pattern is observed when analyzing the content of mobile phosphorus in the soil. In the variant with two irrigation, its amount is $13.0 \mathrm{mg} / \mathrm{kg}$ and $12.2 \mathrm{mg} / \mathrm{kg}$ at a depth of $0-5 \mathrm{~cm}$ and $5-10 \mathrm{~cm}$, respectively, which is more by 2.5 and $1.7 \mathrm{mg} / \mathrm{kg}$ of soil than in the control variant.

Thus, it was revealed that carrying out sprinkler irrigation after capital planning in crop rotation fields, in addition to provoking weeds and wild red rice with the aim of their further destruction, Furthermore, creates favorable conditions for microbiological processes in the soil, as a result of which mineralization of organic substances occurs and its fertility increases. 
In the following year, after carrying out the repair planning of basins and sprinkler irrigation, a pre-sowing cultivation complex was implemented on the same fields, including disking, harrowing, followed by rolling and sowing rice with elite Rapan seeds.

During the growing season, the experiment, the volume of water supplied to the basins was taken into account to maintain the water regime according to the accepted technology in Russia, and the irrigation rate of rice was calculated according to the experimental variants (Table 3 ).

Table 3. The main indicators of water supply during the growing season of Rapan rice variety by experience variant.

\begin{tabular}{|c|c|c|c|c|c|c|}
\hline \multirow[b]{2}{*}{$\begin{array}{l}\text { Experience } \\
\text { variants }\end{array}$} & \multicolumn{5}{|c|}{ Volume of water supply. м3 } & \multirow[b]{2}{*}{$\begin{array}{c}\text { Irrigation } \\
\text { rate. } \\
\text { m3/ha }\end{array}$} \\
\hline & $\begin{array}{l}\text { Seedlings - } \\
\text { technological } \\
\text { discharge }\end{array}$ & $\begin{array}{c}\text { Tillering } \\
- \\
\text { flowering }\end{array}$ & $\begin{array}{l}\text { flowering - } \\
\text { sweeping }\end{array}$ & $\begin{array}{l}\text { ripening - } \\
\text { full ripeness }\end{array}$ & Total & \\
\hline I & 44020.1 & 38517.6 & 14306.5 & 13206.1 & 110050.3 & 18974.2 \\
\hline II & 28561.0 & 27809.4 & 11274.1 & 7516.1 & 75160.6 & 17895.4 \\
\hline III & 38499.8 & 31166.5 & 11916.6 & 10083.2 & 91666.1 & 17628.1 \\
\hline
\end{tabular}

The analysis of the obtained data presented in Table 3 shows a decrease in the irrigation rate for the experimental variants. The value of this indicator was maximum in the variant without sprinkler irrigation $(18974.2 \mathrm{~m} 3 / \mathrm{ha})$, minimal in the third variant with two sprinkler irrigation $(17628.1 \mathrm{~m} 3 / \mathrm{ha}$ ) (minus $1346.1 \mathrm{~m} 3$ /ha to the control). This was facilitated not only by the absence of weed vegetation on the rice basin, but also by reducing the irrigation rate due to the exclusion of technological discharges for treating rice with herbicides, according to the technology of rice cultivation.

Rice, by its nature a hygrophyte (in hygrophytes), nonetheless negatively reacts to flooding in the "germination - seedlings" phase, which is expressed in a decrease in field germination and yield. The maximum yield is ensured by the optimal plant density and their survival to harvest $[10,11]$. In our studies, after the capital planning of the basins, favorable conditions for seed germination and plant survival were formed (Table 4).

Table 4. Values of characteristics that determine the productivity of Rapan rice variety, according to the experience variants.

\begin{tabular}{|c|c|c|c|c|}
\hline \multirow{2}{*}{$\begin{array}{c}\text { Experience } \\
\text { variants }\end{array}$} & \multirow{2}{*}{$\begin{array}{c}\text { Field germination } \\
\text { of seeds. \% }\end{array}$} & \multicolumn{2}{|c|}{ Plant density. pcs/m2 } & \multirow{2}{*}{ Plant survival. } \\
\cline { 3 - 5 } & seedlings & before harvesting & \\
\hline I & 34.7 & 243 & 226 & 93.0 \\
\hline II & 56.6 & 396 & 382 & 96.5 \\
\hline III & 57.4 & 402 & 391 & 97.3 \\
\hline
\end{tabular}

Thus, the field germination of seeds in the control variant without carrying out the repair layout of the basins was $34.7 \%$, while in the third variant of the experiment, this indicator increased to $57.4 \%$, which in turn affected the plant stand density on seedlings and before harvesting. The maximum survival rate of plant was also observed in the III variant $-97.3 \%$, which is $5.3 \%$ more than in the control.

Rice yield is an integral indicator and depends not only on rice variety, but also on environmental factors, including crop cultivation technology, water regime, mineral 
nutrition of the plant and others. In our experience, the average yield was $7.74 \mathrm{t} / \mathrm{ha}$ with a minimum control value of $7.28 \mathrm{t} /$ ha (Table 5 ).

Table 5. The main indicators of harvesting of Rapan rice variety according to the experience variants.

\begin{tabular}{|c|c|c|c|c|c|}
\hline \multirow{2}{*}{$\begin{array}{l}\text { Experience } \\
\text { variants }\end{array}$} & \multicolumn{3}{|c|}{ Indicator } & \multirow{2}{*}{$\begin{array}{c}+/- \text { to } \\
\text { control. } t / \\
\text { ha }\end{array}$} & \multirow{2}{*}{$\begin{array}{c}+/- \text { to } \\
\text { control. } \%\end{array}$} \\
\hline & Area. ha & Total yield. t & $\begin{array}{c}\text { Productivity. } \\
\text { t / ha }\end{array}$ & & \\
\hline I & 5.8 & 42.2 & 7.28 & - & - \\
\hline II & 4.2 & 33.0 & 7.86 & 0.58 & 8 \\
\hline III & 5.2 & 42.1 & 8.09 & 0.81 & 11 \\
\hline HCP05 & & & 5.23 & & \\
\hline
\end{tabular}

The maximum yield of Rapan rice variety was obtained in the third test variant (8.09 $\mathrm{t} / \mathrm{ha}$ ), where two sprinkler irrigation was carried out in rice crop rotation after the repair plan of the basin. The yield increase was from 4.0 to $8.1 \mathrm{~kg} / \mathrm{ha}$ according to the experimental variants, or from 5.5 to $11.2 \%$ in relation to the control.

\section{Conclusions}

Carrying out sprinkler irrigation after the repair planning of basins is an effective agricultural method, which allows to increase the provocation of weeds by 2.8-4.0 times compared to the variant in which seedlings of weeds were obtained due to natural rainfall. In addition, these measures in the field of rice crop rotation increase soil fertility, increase the humus content by 7.7-17.6\% compared with the control, exchange potassium from 5.6 to $7.0 \mathrm{mg} / \mathrm{kg}$ and mobile phosphorus with 10.5 to $12.2 \mathrm{mg} / \mathrm{kg}$ of soil in the arable horizon, reduce the content of nitrate-nitrogen due to leaching and increase the activity of denitrifying bacteria.

After capital planning of the soil and sprinkler irrigation, favourable conditions are formed for the growth and development of rice plants. Minimizing sharp changes in the terrain on the basin plane, the possibility of shortening the period of water supply and water drainage during technological discharges can increase the field germination of seeds from 34.7 to $57.4 \%$, increase the density of standing plants on seeding from 243 to $402 \mathrm{pcs} / \mathrm{m} 2$ and plant survival from 93 to $97.3 \%$ according to the experimental variants.

In addition, the provocation of weeds and futher sowing of rice eliminates the nonproduction losses of water from technological discharges before the rice is treated with herbicides. This saves water resources. In our studies, the maximum irrigation rate of rice was observed in the control variant $(18974.2 \mathrm{~m} 3 / \mathrm{ha})$, the minimum - in the third variant with two sprinkler irrigation $(17628.1 \mathrm{~m} 3 / \mathrm{ha})$.

Carrying out a set of measures in the fields of rice crop rotation had a positive effect on rice productivity. The increase in yield for the experimental variants was ranged from 0.6 $\mathrm{t} / \mathrm{ha}$ to $0.8 \mathrm{t} / \mathrm{ha}$, or from $8 \%$ to $11 \%$ in relation to the control. 


\section{References}

1. Y. Zhou, L. Li, K. Lin, X.P. Zhu, W.P. Liu, Chirality 21, $421-427$ (2009)

2. P. Xu, J. Diao, D. Liu, Z. Zhou, Chemosphere 83, 1074-1079 (2011)

3. F.G. Iturburu, M. Zömisch, A.M. Panzeri, A.C. Crupkin, V. Contardo-Jara, S. Pflugmacher, M.L. Menone, Toxicol. Chem. 36, 699-708 (2017)

4. N. Mantzos, A. Karakitsou, S. Nikolaki, E. Leneti, I. Konstantinou, Environ. Sci. Pollut. Res. 23, 3481-3490 (2016)

5. X. Chen, S. Yu, L. Han, S. Sun, Y. Zhi, W. Li, Bull. Environ. Contam. Toxicol. 87, 5053 (2011)

6. Y. Qi, D. Liu, M. Luo, X. Jing, P. Wang, Z. Zhou, Chemosphere 146, 315-322 (2016)

7. L. Rong, X. Guo, K. Chen, J. Zhu, S. Li, J. Jiang, J. Microbiol. Biotechnol. 19, 14391446 (2009)

8. H. Zhang, X.Q. Wang, S.L. Zhuang, N. Jin, X.Y. Wang, M.R. Qian, H. Xu, P.P. Qi, Q. Wang, M.H. Wang, J. Agric. Food Chem. 60, 10188-10195 (2012)

9. W.X. Xie Jian, Jian-jun Tanf, Jia-en Zhang, Luo Shi-ming, Xin Chen, Agric. Sci. China 10, 754-761 (2011)

10. M.A. Rahman, Environment and Biological Sciences (ICAEBS'16) 8, 149-151 (2016)

11. T. Liu, J. Diao, S. Di, Z. Zhou, Chemosphere 124, 77-82 (2015)

12. M. Tian, Q. Zhang, X. Hua, B. Tang, B. Gao, M. Wang, J. Hazard. Mater. 320, $487-$ 494 (2016)

13. Z. Yao, M. Lin, M. Xu, T. Wang, X. Ping, S. Wu, Q. Wang, H. Zhang, J. Sep. Sci. 38, 1663-1672 (2015)

14. Y. Wang, D. Dai, Y. Yu, G. Yang, W. Shen, Q. Wang, H. Weng, X. Zhao, J. Hazard. Mater. 352, 80-91 (2018)

15. M.G. Nillos, J. Gan, D. Schlenk, J. Chromatogr. B. 878, 1277-1284 (2010) 